\title{
Efektivitas Audiovisual dan Booklet sebagai Media Edukasi untuk Meningkatkan Perilaku Skrining IVA
}

\author{
Effectiveness of audiovisual and booklet as Education Media to \\ Improving IVA Screening behavior
}

\author{
Veronica Silalahi ${ }^{1}$, Wiwin Lismidiati ${ }^{2}$, Mohammad Hakimi ${ }^{3}$ \\ ${ }^{1}$ Sekolah Tinggi Ilmu Kesehatan Katolik St.Vincentius a Paulo Surabaya \\ ${ }^{2}$ Bagian Ilmu Keperawatan, Fakultas Kedokteran, Universitas Gadjah Mada \\ ${ }^{3}$ Bagian Obstetri dan Ginekologi , Fakultas Kedokteran, Universitas Gadjah Mada \\ (verosilalahi@stikvinc.ac.id)
}

\begin{abstract}
ABSTRAK
Kanker serviks menjadi penyebab tingginya kematian ibu. Pencegahan kanker serviks dapat dilakukan dengan skrining Inspeksi Visual dengan Asam Asetat (IVA). Tujuan penelitian untuk menganalisis efektifitas pendidikan kesehatan dengan menerapkan Health Belief Model (HBM) menggunakan media audiovisual dan booklet terhadap perilaku wanita dalam melakukan pemeriksaan IVA di wilayah kerja Puskesmas Pacarkeling Surabaya. Metode penelitian menggunakan Quasi Experimental dengan desain Non Equivalent Control Group Design. Subjek penelitian wanita berusia 30-50 tahun yang belum pernah melakukan pemeriksaan IVA sebelumnya. Pemilihan sampel menggunakan teknik cluster sampling dengan jumlah sampel 79 responden untuk masing-masing kelompok intervensi dan kelompok kontrol. Pendidikan kesehatan menggunakan media audiovisual dan booklet. Data diolah menggunakan uji wilcoxon, chi-square, mann-whitney, dan regresi linier. Hasil penelitian menunjukkan pendidikan kesehatan menggunakan media audiovisual dan booklet efektif dalam meningkatkan perilaku responden dalam melakukan skrining IVA. Peningkatan pengetahuan, sikap, kepercayaan kesehatan kelompok intervensi lebih besar dibandingkan dengan kelompok kontrol. Perilaku wanita dalam melakukan skrining IVA pada kelompok intervensi lebih besar dibandingkan dengan kelompok kontrol setelah diberikan intervensi. Variabel luar seperti usia, pendidikan, pekerjaan, penghasilan, informasi sebelumnya memiliki pengaruh terhadap peningkatan perilaku. Pendidikan kesehatan efektif dalam meningkatkan perilaku wanita melakukan pemeriksaan IVA.
\end{abstract}

Kata Kunci : Pendidikan kesehatan, perilaku, IVA, HBM

\section{ABSTRACT}

Cervical cancer is the caused of high maternal mortality. Prevention of cervical cancer done by screening Visual Inspection with Acetic Acid (IVA). The objective of this study to analyzed the effectiveness of health education applying health belief model using audiovisual and booklet on female behavior for IVA examination in the work area of Pacarkeling Public Health Center. The research method used Quasi Experimental with Design NonEquivalent Control Group Design. Research subjects were women aged 30-50 years who have never done previous IVA examination. Sample selection using cluster sampling technique with sample of 79 respondents for each group of intervention and control group. Health education using audiovisual and booklet. Data analyzed using wilcoxon test, chi-square, mann-whitney, and linear regression. Health education using audiovisual and booklet effective in improving the behavior of respondents for IVA screening. Increased of knowledge, attitudes, health belief of the intervention group is greater than control group. The behavior of women in IVA screening for intervention group was greater than control group after intervention. External variables such as age, education, occupation, income, previous information have an effect on behavior improvement. Health education is effective in improving women behavior for IVA screening.

Keywords : Health education, behavior, IVA, HBM 


\section{PENDAHULUAN}

Kesehatan perempuan merupakan salah satu indikator pencapaian kesehatan di dunia, termasuk di Indonesia. Masalah kesehatan perempuan masih menjadi tugas bagi pemerintah dan tenaga kesehatan, terkait tingginya angka kematian ibu. Penyebab tingginya angka kematian ibu salah satunya kanker serviks yang merupakan penyakit pada sistem reproduksi yang disebabkan oleh $70 \%$ HPV onkogenik tipe 16 dan $18 .{ }^{1}$

Data yang diperoleh dari International Agency for Research on Cancer (IARC) WHO pada tahun 2012 terdapat 527,624 kasus baru dengan kanker serviks yang dialami oleh wanita di seluruh dunia dengan jumlah 14,1 juta kasus. ${ }^{2}$ Jumlah kanker serviks tersebut $85 \%$ terjadi di negara berkembang, termasuk negara Indonesia. Data dari Dinas Kesehatan Provinsi Jawa Timur tahun 2014 terdapat 3813 wanita dengan kanker serviks. ${ }^{4}$ Data yang didapatkan dari Dinas Kesehatan Kota Surabaya tahun 2014, terdapat 265 pasien dengan kanker serviks dan jumlah pasien kanker serviks sampai dengan Juni 2015 terdapat 194 pasien. Data tersebut diambil dari 62 puskesmas yang tersebar di Kota Surabaya. ${ }^{5}$ Perbandingan antara penderita kanker serviks dengan tempat pelayanan (puskesmas) masih belum ideal. Seharusnya setiap puskesmas yang ada di Jatim mampu memberikan pelayanan berupa pap smear dan IVA, akan tetapi dari 961 puskesmas baru $60 \%$ yang bisa memberikan pelayanan Pap smear dan IVA. ${ }^{4}$ Data yang didapatkan dari hasil rekapitulasi Puskesmas Pacarkeling tahun 2015, terdapat 152 pasien kanker servik ( 7 kasus baru, dan 112 kasus lama, dan 33 kasus lama dengan rujukan) dan rata-rata usia pasien mencapai 30 tahun hingga 55 tahun. Kanker serviks di Puskemas Pacar Keling adalah kanker ke dua terbanyak setelah kanker payudara.

Skrining IVA di Puskesmas Pacarkeling merupakan salah satu program unggulan dan dilakukan setiap hari Selasa. Pemerintah memberi target pada setiap puskesmas untuk memberikan layanan IVA kepada 10 pasien setiap bulan. Jumlah pasien yang melakukan skrining IVA pada tahun 2015 sebanyak 109 pasien, menurun dari tahun 2014 sebanyak 155 pasien. Pada tahun 2015 target yang harus dipenuhi oleh puskesmas belum tercapai. Puskesmas Pacarkeling juga memiliki program penyuluhan setiap bulannya, tetapi media penyuluhan yang diberikan hanya berupa leaflet atau flipchart, dan metodenya berupa ceramah. Hasil wawancara yang dilakukan kepada 9 wanita pengunjung Puskesmas Pacarkeling, 6 diantaranya mengungkapkan bahwa pernah mendengar tentang kanker serviks dan skrining kanker serviks seperti IVA atau Pap Smear, tetapi menolak untuk melakukan karena ada rasa khawatir, malu, takut bila hasil pemeriksaan positif, sakit saat dilakukan pemeriksaan, dan mengungkapkan bahwa pemeriksaan tersebut tidak perlu dilakukan karena merasa sehat-sehat saja, tidak memiliki riwayat keluarga dengan kanker serviks, skrining IVA dilakukan bila ada gejala yang muncul, sedangkan 3 wanita belum tahu tentang IVA maupun Pap smear.

Salah satu strategi untuk merubah perilaku, seperti mencegah kanker serviks dengan memberikan informasi melalui pendidikan kesehatan yang dapat meningkatkan pengetahuan masyarakat tentang perilaku sehat. ${ }^{6}$ Penelitian yang dilakukan Khademolhosseini et al., bahwa pendidikan kesehatan dengan menerapkan Health Belief Model efektif dalam meningkatkan keikutsertaan wanita melakukan pap smear test. ${ }^{7}$ Hal ini juga didukung oleh penelitian Shojaeizaddeh, et al., dan teori yang disampaikan oleh Glanz et al., mengungkapkan bahwa pendidikan kesehatan dengan penerapan Health Belief Model, efektif meningkatkan pengetahuan peserta secara signifikan, mengubah keyakinan kesehatan dan meningkatkan perilaku mereka mengenai program skrining. ${ }^{7,8}$ Health $\mathrm{Be}$ lief Model penting digunakan untuk mengembangkan program pencegahan penyakit dan salah satu framework digunakan untuk memahami perilaku kesehatan. Rasional dari Health Belief Model didasarkan atas perilaku masyarakat yang ingin merubah perilaku kesehatan yang negatif, mencegah penyakit, dan menjaga kesehatan. ${ }^{9}$

Pendidikan dapat diberikan menggunakan beberapa media, seperti audiovisual dan booklet. Pendidikan kesehatan menggunakan media audiovisual, dapat meningkatkan pengetahuan dan partisipasi wanita dalam program deteksi dini kanker serviks yaitu IVA. ${ }^{9}$ Booklet juga dapat mempengaruhi peningkatkan pengetahuan dan sikap, dibandingkan dengan media visual seperti poster. ${ }^{10,11}$ Media booklet digunakan untuk mendorong keinginan seseorang untuk mengetahui kemudian mendalami dan akhirnya mendapatkan pengertian 
yang baik dan pendorong untuk melakukan sesuatu yang baru ${ }^{11}$, dan media audiovisual untuk memberikan stimulus pada pendengaran dan penglihatan sehingga hasil yang diperoleh bisa maksimal. ${ }^{6}$ Dalam penelitian ini, peneliti melakukan intervensi pendidikan kesehatan dengan menerapkan Health Belief Model menggunakan media audiovisual dan booklet untuk mengetahui efektivitasnya terhadap perilaku wanita dalam melakukan skrining IVA di wilayah kerja Puskesmas Pacarkeling Surabaya.

\section{BAHAN DAN METODE}

Jenis penelitian adalah Quasi Experimental dengan desain Non equivalent Control Group Design. Penelitian dilakukan pada bulan Agustus tahun 2016 di wilayah kerja Puskesmas Pacarkeling Surabaya, yaitu Kelurahan Pacarkeling dan Kelurahan Pacarkembang Surabaya, dengan waktu pengukuran sebanyak tiga kali yaitu pre-test pada minggu I, post-test 1 pada minggu II, dan post-test II pada minggu IV. Populasi dalam penelitian ini adalah semua wanita yang berada wilayah kerja Puskesmas Pacarkeling Surabaya. Sampel dalam penelitian ini wanita yang berada di Kelurahan Pacarkeling dan Kelurahan Pacarkembang yang berjumlah 79 responden untuk masing-masing kelompok intervensi dan kontrol. Peneliti melakukan pengambilan sampel menggunakan cluster sampling. Pendidikan kesehatan diberikan kepada responden sebanyak satu kali pada minggu I menggunakan media audiovisual dan booklet untuk kelompok intervensi dan media audiovisual untuk kelompok kontrol. Booklet berisi penjelasan tentang kanker serviks dan metode skrining kanker serviks. Penjelasan booklet dilakukan selama 30 menit dan peserta diberikan kesempatan untuk membaca selama 20 menit. Media audiovisual berupa video tentang kanker serviks, pencegahan dan pemeriksaan kanker serviks yang berdurasi 6 menit. Untuk mengurangi bias, pendidikan kesehatan diberikan oleh kader yang telah dilatih terlebih dahulu.

Pengetahuan dan sikap diukur dengan kuesioner yang telah diuji validitas dan reliabilitasnya oleh peneliti sebelumnya dengan hasil nilai alpha variabel pengetahuan $=0.90$ dan nilai alpha variabel sikap $=0.99^{12}$, perilaku dinilai dengan memberikan kuesioner lembar keikutsertaan respon- den melakukan skrining IVA untuk mengetahui responden telah melakukan skrining atau tidak. Komponen kepercayaan kesehatan atau health belief model (terdiri dari 6 komponen) diukur dengan kuesioner yang sebelumnya telah diuji validitas dan reliabilitasnya oleh peneliti sendiri dengan nilai $r>0.3$ dan masing-masing komponen HBM dengan nilai alpha $>0.7$. Analisa data dengan uji univariat, uji bivariat dan uji multivariat. Uji normalitas data dilakukan dengan menggunakan uji Kolmogorov-Smirnov. ${ }^{13}$ Analisa data untuk masing-masing kelompok intervensi dan kelompok kontrol menggunakan repeated ANOVA. Untuk mengetahui kelompok mana yang berbeda variabelnya secara bermakna, dilakukan analisis Post-Hoc. Analisis Post-Hoc untuk uji Friedman adalah uji Wilcoxon dengan nilai signifikan $\mathrm{p}<0.05$. Untuk mengetahui rerata kenaikan pengetahuan, sikap, dan kepercayaan kesehatan, dianalisis menggunakan Mann-Whitney dengan tingkat kemaknaan $\alpha=0.05$. Analisis perilaku wanita dalam melakukan skrining dengan uji $C h i$ Square. Uji multivariat dengan analisis regresi linier metode backward. Penelitian ini telah mendapatkan persetujuan etik dari Komisi Etik Penelitian Kedokteran dan Kesehatan Fakultas Kedokteran, Universitas Gadjah Mada, Yogyakarta.

\section{HASIL}

Data karakteristik responden pada Tabel 1 didapatkan bahwa rata-rata usia responden pada kelompok intervensi adalah 35 tahun, 42 orang (53.2\%) berpendidikan SMA, tidak bekerja sebanyak 46 orang (58.2\%), jumlah penghasilan $<$ Rp. 3.045.000 sebanyak 67 orang $(84.8 \%)$, dan sudah pernah mendapatkan informasi sebelumnya sebanyak 40 orang (50.6\%). Pada kelompok kontrol, rata-rata usia 37 tahun dan lebih dari setengah berpendidikan menengah atau SMA $(75.9 \%)$, tidak bekerja $(58.2 \%)$, jumlah penghasilan $<\mathrm{Rp}$. 3.045.000 (79.7\%), dan sudah pernah mendapatkan informasi sebelumnya (58.2\%). Pada kelompok kontrol, rata-rata usia 37 tahun dan 60 orang (75.9\%) berpendidikan SMA, bekerja sebanyak 46 orang $(58.2 \%)$, jumlah penghasilan $<\mathrm{Rp}$. 3.045 .000 sebanyak 46 orang $(79.7 \%)$, dan sudah pernah mendapatkan informasi sebelumnya sebanyak 46 orang $(58.2 \%)$. 
Tabel 1. Karakteristik Responden

\begin{tabular}{|c|c|c|c|c|}
\hline \multirow{3}{*}{ Karakteristik } & \multicolumn{4}{|c|}{ Subjek Penelitian } \\
\hline & \multicolumn{2}{|c|}{ Kelompok Intervensi $(n=79)$} & \multicolumn{2}{|c|}{ Kelompok Kontrol $(n=79)$} \\
\hline & $\mathbf{n}(\%)$ & Mean \pm SD & $\mathbf{n}(\%)$ & Mean \pm SD \\
\hline Usia (tahun) & & $35.38 \pm 4.502$ & & $36.58 \pm 5.358$ \\
\hline $30-40$ & $67(84.8)$ & & $63(79.7)$ & \\
\hline $41-50$ & $12(15.2)$ & & $16(20.3)$ & \\
\hline \multicolumn{5}{|l|}{ Pendidikan } \\
\hline Pendidikan Dasar & $24(30.4)$ & & $7(8.9)$ & \\
\hline Pendidikan Menengah & $42(53.2)$ & & $60(75.9)$ & \\
\hline Pendidikan Tinggi & $13(16.5)$ & & $12(15.2)$ & \\
\hline \multicolumn{5}{|l|}{ Pekerjaan } \\
\hline Bekerja & $33(41.8)$ & & $46(58.2)$ & \\
\hline Tidak Bekerja & $46(58.2)$ & & $33(41.8)$ & \\
\hline \multicolumn{5}{|l|}{ Penghasilan } \\
\hline$<$ Rp. 3.045 .000 & $67(84.8)$ & & $63(79.7)$ & \\
\hline$>$ Rp. 3.045 .000 & $12(15.2)$ & & $16(20.3)$ & \\
\hline \multicolumn{5}{|l|}{ Informasi sebelumnya } \\
\hline Sudah Pernah Mendapatkan Informasi & $40(50.6)$ & & $46(58.2)$ & \\
\hline Belum Pernah Mendapatkan Informasi & $39(49.4)$ & & $33(41.8)$ & \\
\hline
\end{tabular}

Sumber : Data Primer, 2016

Hasil uji univariat pada Tabel 2 didapatkan rata-rata skor pengetahuan kelompok intervensi yaitu 65.61, rata-rata skor sikap 67.03. Rata-rata skor untuk penilaian komponen kepercayaan kesehatan pada Tabel 2 untuk kelompok intervensi adalah kerentanan yang dirasakan 15.47, keparahan yang dirasakan 18.71, manfaat yang dirasakan 22.75 , hambatan yang dirasakan 22.58 , isyarat untuk melakukan 18.08, dan efikasi diri 13.06. Pada kelompok kontrol, rata-rata skor pengetahuan yaitu 69.94, rata-rata skor sikap 70.78. Rata-rata skor untuk penilaian komponen kepercayaan kesehatan untuk kelompok kontrol adalah kerentanan yang dirasakan 16.73, keparahan yang dirasakan 19.97, manfaat yang dirasakan 24.76, hambatan yang dirasakan 21.76, isyarat untuk melakukan 20.09, dan efikasi diri 13.92.

Hasil uji bivariat didahului dengan melakukan uji normalitas dan didapatkan variabel pengetahuan, sikap, kepercayaan kesehatan dan keikutsertaan melakukan skrining pada kelompok intervensi dan kelompok kontrol berdistribusi tidak normal dengan nilai masing-masing $p<0.05$. Uji bivariat dilakukan dengan uji repeated ANOVA karena pengukuran dilakukan berulang sebanyak 3 kali yaitu pretest, posttest 1 , dan posttest 2 . Oleh karena variabel penelitian ini tidak berdistribusi normal, sehingga uji repeated ANOVA tidak dapat dilakukan dan uji alternatifnya adalah Friedman. Untuk mengetahui kelompok mana yang berbeda variabel secara bermakna pada kedua kelompok, harus dilakukan analisis Post-Hoc. Analisis PostHoc untuk uji Friedman adalah dengan uji Wilcoxon.

Hasil uji Wilcoxon pada Tabel 3 menunjukkan bahwa terdapat perbedaan pengetahuan pada kelompok intervensi dan kelompok kontrol untuk pengukuran sebelum (pre-test) dan sesudah intervensi (post-test 1 dan post-test 2). Pada variabel sikap yang tercantum pada Tabel 3, didapatkan perbedaan sikap pada kelompok intervensi untuk pengukuran sebelum (pre-test) dan sesudah intervensi (post-test 1 dan post-test 2 ). Terdapat perbedaan sikap pada kelompok kontrol sebelum dan sesudah intervensi (post-test 1), tetapi tidak terdapat perbedaan sikap sebelum dan sesudah intervensi (post-test 2). Variabel kepercayaan kesehatan pada Tabel 3, didapatkan komponen kepercayaan kesehatan pada kelompok intervensi yaitu kerentanan kesehatan, manfaat yang dirasakan, efikasi diri dan isyarat untuk melakukan terdapat perbedaan sebelum dan sesudah diberikan pendidikan kesehatan (post-test 1 dan post-test 2 ), sedangkan komponen keparahan yang dirasakan dan hambatan yang dirasakan, tidak memiliki perbedaan sebelum dan setelah pendidikan kesehatan pada pe- 
Tabel 2. Pengaruh Pendidikan Kesehatan terhadap Pengetahuan, Sikap, Kepercayaan Kesehatan Sebelum dan Sesudah Diberikan Intervensi

\begin{tabular}{|c|c|c|c|c|c|c|}
\hline \multirow[b]{2}{*}{ Variabel } & \multicolumn{2}{|c|}{ Intervensi } & \multirow[b]{2}{*}{$\mathbf{p}$} & \multicolumn{2}{|c|}{ Kontrol } & \multirow[b]{2}{*}{$\mathbf{p}$} \\
\hline & $\begin{array}{l}\text { Pretest Median } \\
\quad(\min -\text { max })\end{array}$ & $\begin{array}{c}\text { Rerata } \\
\pm \text { s.b. }\end{array}$ & & $\begin{array}{l}\text { Pretest Median } \\
(\text { min - max })\end{array}$ & $\begin{array}{c}\text { Rerata } \\
\pm \text { s.b. }\end{array}$ & \\
\hline \multicolumn{7}{|l|}{ Pengetahuan } \\
\hline Pretest & $65.00(45-95)$ & $65.51 \pm 11.99$ & $<0.001$ & $70.00(45-85)$ & $69.94 \pm 10.73$ & $<0.001$ \\
\hline Post test 1 & $85.00(70-95)$ & $82.59 \pm 4.73$ & & $80.00(70-85)$ & $80.63 \pm 3.87$ & \\
\hline Post test 2 & $100.00(85-100)$ & $97.47 \pm 3.83$ & & $95.00(85-100)$ & $95.06 \pm 5.03$ & \\
\hline \multicolumn{7}{|l|}{ Sikap } \\
\hline Pretest & $68.00(46-87)$ & $67.03 \pm 9.28$ & $<0.001$ & $72.00(54-89)$ & $70.78 \pm 8.32$ & 0.000 \\
\hline Post test 1 & $83.00(75-94)$ & $83.81 \pm 3.91$ & & $82.00(75-90)$ & $81.77 \pm 3.10$ & 0.000 \\
\hline Post test 2 & $86.00(75-94)$ & $85.62 \pm 4.01$ & & $83.00(69-91)$ & $82.91 \pm 4.87$ & 0.065 \\
\hline \multicolumn{7}{|l|}{$\begin{array}{l}\text { Kepercayaan Kesehatan } \\
\text { Kerentanan yang dirasakan }\end{array}$} \\
\hline Pretest & $16.00(7-22)$ & $15.47 \pm 3.45$ & & $17.00(9-23)$ & $16.73 \pm 3.05$ & \\
\hline Post test 1 & $20.00(17-23)$ & $20.43 \pm 1.50$ & & $18.00(14-23)$ & $18.49 \pm 1.48$ & \\
\hline Post test 2 & $21.00(18-24)$ & $21.11 \pm 1.71$ & & $19.00(18-23)$ & $19.42 \pm 1.20$ & \\
\hline Pre-Post test 1 & & & 0.000 & & & 0.000 \\
\hline Pre-Post test 2 & & & 0.000 & & & 0.000 \\
\hline Post test 1 -Post test 2 & & & 0.007 & & & 0.000 \\
\hline \multicolumn{7}{|l|}{ Keparahan yang dirasakan } \\
\hline Pretest & $20.00(11-26)$ & $18.71 \pm 4.35$ & & $20.00(11-27)$ & $19.97 \pm 3.77$ & \\
\hline Post test 1 & $25.00(16-28)$ & $24.13 \pm 3.02$ & & $23.00(16-28)$ & $22.56 \pm 2.71$ & \\
\hline Post test 2 & $24.00(19-28)$ & $23.89 \pm 1.86$ & & $23.00(18-28)$ & $22.86 \pm 1.85$ & \\
\hline Pre-Post test 1 & & & 0.000 & & & 0.000 \\
\hline Pre-Post test 2 & & & 0.000 & & & 0.000 \\
\hline Post test 1 -Post test 2 & & & 0.392 & & & 0.600 \\
\hline \multicolumn{7}{|l|}{ Manfaat yang dirasakan } \\
\hline Pretest & $24.00(13-31)$ & $22.75 \pm 4.98$ & & $25.00(14-33)$ & $24.76 \pm 3.96$ & \\
\hline Post test 1 & $32.00(22-35)$ & $31.27 \pm 3.23$ & & $31.00(24-35)$ & $30.41 \pm 2.46$ & \\
\hline Post test 2 & $31.00(25-35)$ & $30.28 \pm 2.50$ & & $31.00(25-35)$ & $30.28 \pm 2.50$ & \\
\hline Pre-Post test 1 & & & 0.000 & & & 0.000 \\
\hline Pre-Post test 2 & & & 0.000 & & & 0.000 \\
\hline Post test 1-Post test 2 & & & 0.029 & & & 0.798 \\
\hline \multicolumn{7}{|l|}{ Hambatan yang dirasakan } \\
\hline Pretest & $23.00(11-32)$ & $22.58 \pm 5.11$ & & $20.00(12-34)$ & $21.76 \pm 4.71$ & \\
\hline Post test 1 & $17.00(9-26)$ & $16.23 \pm 3.76$ & & $17.00(9-25)$ & $15.99 \pm 3.61$ & \\
\hline Post test 2 & $17.00(9-20)$ & $16.46 \pm 2.23$ & & $18.00(9-23)$ & $17.53 \pm 2.32$ & \\
\hline Pre-Post test 1 & & & 0.000 & & & 0.000 \\
\hline Pre-Post test 2 & & & 0.000 & & & 0.000 \\
\hline Post test 1-Post test 2 & & & 0.480 & & & 0.350 \\
\hline \multicolumn{7}{|l|}{ Efikasi Diri } \\
\hline Pretest & $14.00(8-19)$ & $13.06 \pm 2.81$ & & $14.00(8-20)$ & $13.92 \pm 2.87$ & \\
\hline Post test 1 & $17.00(13-20)$ & $17.14 \pm 2.03$ & & $15.00(13-20)$ & $15.70 \pm 1.67$ & \\
\hline Post test 2 & $18.00(15-20)$ & $17.58 \pm 2.04$ & & $15.00(14-20)$ & $16.47 \pm 1.91$ & \\
\hline Pre-Post test 1 & & & 0.000 & & & 0.000 \\
\hline Pre-Post test 2 & & & 0.000 & & & 0.000 \\
\hline Post test 1 -Post test 2 & & & 0.008 & & & 0.017 \\
\hline \multicolumn{7}{|l|}{ Isyarat untuk Melakukan } \\
\hline Pretest & $18.00(7-26)$ & $18.08 \pm 4.06$ & & $21.00(11-28)$ & $20.09 \pm 3.90$ & \\
\hline Post test 1 & $23.00(17-28)$ & $23.23 \pm 2.25$ & & $21.00(17-28)$ & $20.80 \pm 1.43$ & \\
\hline Posttest 2 & $24.00(20-28)$ & $24.23 \pm 2.13$ & & $22.00(20-28)$ & $22.67 \pm 1.77$ & \\
\hline Pre-Post test 1 & & & 0.000 & & & 0.000 \\
\hline Pre-Post test 2 & & & 0.000 & & & 0.000 \\
\hline Post test 1 -Post test 2 & & & 0.008 & & & 0.000 \\
\hline
\end{tabular}

*menggunakan uji wilxocon sebagai alternatif dari uji repeated ANOVA 
Tabel 3. Delta Kenaikan Pengetahuan, Sikap, dan Kepercayaan Kesehatan Sebelum dan Sesudah Diberikan Pendidikan Kesehatan

\begin{tabular}{|c|c|c|c|c|c|}
\hline Variabel & Waktu Pengukuran & $\begin{array}{c}\text { Kelompok } \\
\text { Intervensi } \\
\text { Mean (SD) }\end{array}$ & $\begin{array}{c}\text { Kelompok } \\
\text { Kontrol } \\
\text { Mean (SD) } \\
\end{array}$ & $\begin{array}{l}\text { Selisih } \\
\text { Rerata }\end{array}$ & $\mathbf{p}$ \\
\hline \multirow[t]{3}{*}{ Pengetahuan } & Post test 1-pretest & $17.09 \pm 13.41$ & $10.69 \pm 10.70$ & 6.39 & 0.002 \\
\hline & Post test 2-pretest & $31.96 \pm 12.23$ & $25.13 \pm 12.43$ & 6.83 & 0.001 \\
\hline & Post test 2-Post test 1 & $14.87 \pm 6.30$ & $14.43 \pm 6.79$ & 0.44 & 0.616 \\
\hline \multirow[t]{3}{*}{ Sikap } & Post test 1-pretest & $16.78 \pm 10.26$ & $10.98 \pm 9.37$ & 5.8 & 0.001 \\
\hline & Post test 2-pretest & $18.60 \pm 9.75$ & $12.12 \pm 9.53$ & 6.48 & 0.000 \\
\hline & Post test 2-Post test 1 & $1.81 \pm 5.85$ & $1.13 \pm 5.85$ & 0.5 & 0.636 \\
\hline \multicolumn{6}{|l|}{ Kepercayaan } \\
\hline \multirow{3}{*}{$\begin{array}{l}\text { Kerentanan yang } \\
\text { dirasakan }\end{array}$} & Post test 1-pretest & $4.96 \pm 3.92$ & $1.75 \pm 3.41$ & 3.21 & 0.000 \\
\hline & Post test 2-Pretest & $5.64 \pm 3.80$ & $2.68 \pm 3.39$ & 2.96 & 0.000 \\
\hline & Post test 2-Post test 1 & $0.68 \pm 2.19$ & $0.92 \pm 2.02$ & 0.24 & 0.000 \\
\hline \multirow{3}{*}{$\begin{array}{l}\text { Keparahan } \\
\text { yang dirasakan }\end{array}$} & Post test 1-pretest & $5.41 \pm 6.12$ & $2.58 \pm 4.73$ & 2.83 & 0.003 \\
\hline & Post test 2-Pretest & $5.17 \pm 4.86$ & $2.88 \pm 4.38$ & 2.29 & 0.001 \\
\hline & Post test 2-Post test 1 & $-0.24 \pm 3.66$ & $0.30 \pm 3.14$ & 0.06 & 0.184 \\
\hline \multirow{3}{*}{$\begin{array}{l}\text { Manfaat yang } \\
\text { dirasakan }\end{array}$} & Post test 1-pretest & $8.51 \pm 6.46$ & $5.64 \pm 5.16$ & 2.87 & 0.004 \\
\hline & Post test 2-Pretest & $7.53 \pm 5.72$ & $5.51 \pm 5.15$ & 2.02 & 0.031 \\
\hline & Post test 2-Post test & $-0.98 \pm 4.02$ & $-0.12 \pm 3.35$ & 0.86 & 0.097 \\
\hline \multirow{3}{*}{$\begin{array}{l}\text { Hambatan yang } \\
\text { dirasakan }\end{array}$} & Post test 1-pretest & $-6.35 \pm 5.97$ & $-5.77 \pm 6.18$ & 0.58 & 0.416 \\
\hline & Post test 2-Pretest & $-6.12 \pm 5.68$ & $-4.22 \pm 5.72$ & 1.90 & 0.023 \\
\hline & Post test 2-Post test 1 & $0.22 \pm 4.50$ & $1.54 \pm 4.55$ & 1.32 & 0.106 \\
\hline \multirow[t]{3}{*}{ Efikasi Diri } & Post test 1-pretest & $4.07 \pm 3.43$ & $1.77 \pm 3.28$ & 2.30 & 0.000 \\
\hline & Post test 2-Pretest & $4.51 \pm 3.21$ & $2.54 \pm 3.83$ & 1.97 & 0.000 \\
\hline & Post test 2-Post test 1 & $0.44 \pm 2.95$ & $0.77 \pm 2.59$ & 0.33 & 0.000 \\
\hline \multirow{3}{*}{$\begin{array}{l}\text { Isyarat untuk } \\
\text { melakukan }\end{array}$} & Post test 1-pretest & $5.15 \pm 4.80$ & $0.70 \pm 4.05$ & 4.45 & 0.000 \\
\hline & Post test 2-Pretest & $6.15 \pm 4.79$ & $2.58 \pm 4.63$ & 3.57 & 0.000 \\
\hline & Post test 2-Post test 1 & $1.00 \pm 2.98$ & $1.87 \pm 2.28$ & 0.87 & 0.014 \\
\hline
\end{tabular}

Uji Mann-Whitney

Tabel 4. Perilaku Wanita dalam Melakukan Skrining IVA Setelah Diberikan Pendidikan Kesehatan

\begin{tabular}{cccccccc}
\hline \multirow{2}{*}{ Kelompok } & \multicolumn{2}{c}{ Skrining IVA } & \multicolumn{2}{c}{ Tidak Skrining IVA } & \multirow{2}{*}{$\mathbf{X}^{2}$} & \multirow{2}{*}{$\mathbf{p}$} \\
\cline { 2 - 5 } & $\mathbf{n}$ & $\mathbf{\%}$ & $\mathbf{n}$ & $\mathbf{\%}$ & & 0.000 \\
& 71 & 89.9 & 7 & 10.1 & 50.24 & 0.000 \\
\hline Intervensi & 58 & 73.4 & 21 & 16.6 & 17.3 & 0.000 \\
Kontrol & & & & & &
\end{tabular}

Uji Chi-Square 


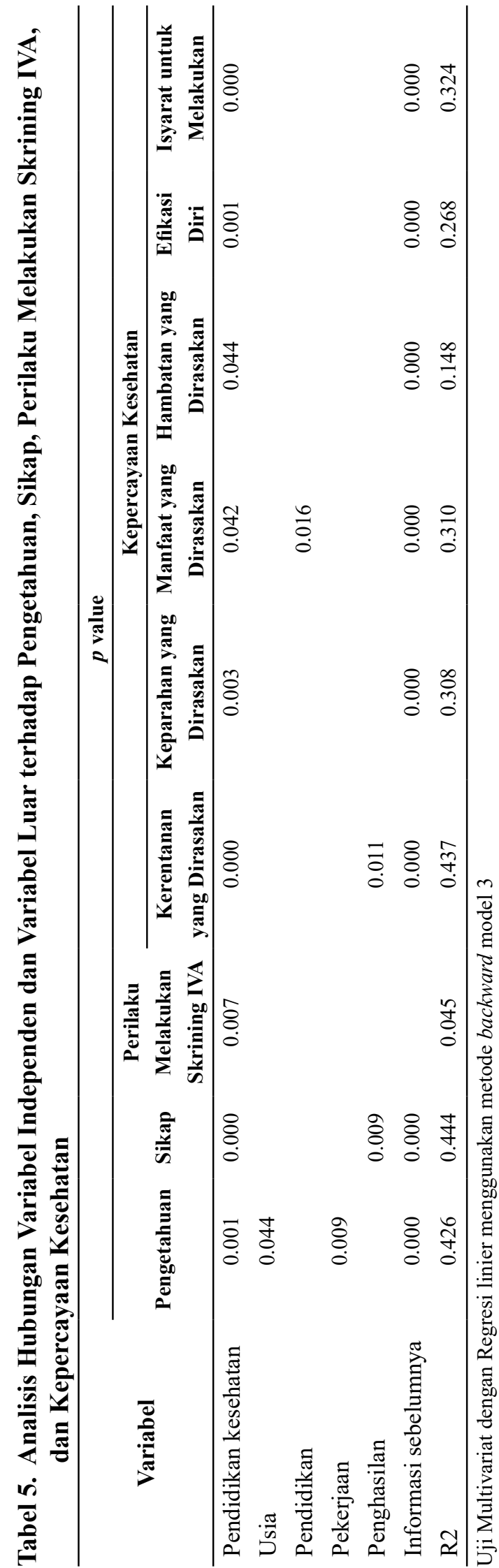

ngukuran ketiga yaitu saat post-test 2. Komponen kepercayaan pada kelompok kontrol yaitu kerentanan yang dirasakan, efikasi diri dan isyarat untuk melakukan, terdapat perbedaan sebelum dan sesudah diberikan pendidikan kesehatan (post-test 1 dan post-test 2), sedangkan untuk komponen keparahan yang dirasakan, manfaat yang dirasakan, hambatan yang dirasakan tidak memiliki perbedaan sebelum dan setelah pendidikan kesehatan pada pengukuran ketiga yaitu saat post-test 2 .

Hasil rerata kenaikan pengetahuan, sikap, dan kepercayaan kesehatan yang tercantum pada Tabel 3 pada kedua kelompok didapatkan peningkatan rata-rata pengetahuan setelah diberikan intervensi (post-test 1) pada kedua kelompok de-ngan nilai $\mathrm{p}<0.005$, tetapi pada post-test 2 dan post-test 1 tidak terdapat peningkatan pengetahuan, dan peningkatan pengetahuan pada kelompok intervensi lebih besar dibandingkan dengan kelompok kontrol. Peningkatan rata-rata sikap setelah diberikan intervensi (post-test 1) pada kedua kelompok dengan nilai $\mathrm{p}<0.005$, sikap pada kelompok intervensi lebih besar dibandingkan dengan kelompok kontrol. Peningkatan rata-rata komponen kepercayaan kesehatan yang tercantum pada Tabel 3 sebelum dan sesudah diberikan pendidikan kesehatan didapatkan $\mathrm{p}<0.05$ (post-test 1 ). Namun, pada pengukuran post-test 1 - post-test 2 tidak ditemukan peningkatan dengan $\mathrm{p}>0.05$. Pada komponen hambatan yang dirasakan, tidak ditemukan rata-rata peningkatan sebelum dan sesudah intervensi (pre test - post test 2) dan saat pengukuran post test 1 - post test 2 dengan nilai $\mathrm{p}<0.05$. Tabel 4 didapatkan data bahwa jumlah wanita yang melakukan skrining IVA lebih banyak pada kelompok intervensi, dibandingkan dengan kelompok kontrol, dan dari analisa data terdapat perbedaan yang bermakna antara kelompok intervensi dan kelompok kontrol sebesar 0.000 .

Hasil uji multivariat pada Tabel 5 didapatkan pendidikan kesehatan, usia, pekerjaan dan informasi sebelumnya berpengaruh terhadap peningkatan pengetahuan dengan nilai $\mathrm{p}<0.05$ dan besarnya pengaruh terhadap peningkatan pengetahuan sebesar $42.6 \%$. Pendidikan kesehatan, penghasilan dan informasi sebelumnya berpengaruh terhadap peningkatan sikap $\mathrm{p}<0.05$ dan besarnya pengaruh adalah $44.4 \%$. Pendidikan kesehatan berpengaruh terhadap peningkatan perilaku wa- 
nita dalam melakukan skrining $\mathrm{p}<0.05$ dan besarnya pengaruh adalah $4.5 \%$. Pendidikan kesehatan, penghasilan dan informasi sebelumnya berpengaruh terhadap peningkatan kepercayaan kesehatan (kerentanan yang dirasakan) dengan nilai $\mathrm{p}<0.05$ dan besarnya pengaruh adalah $43.7 \%$. Pendidikan kesehatan, dan informasi sebelumnya berpengaruh terhadap peningkatan kepercayaan kesehatan (keparahan yang dirasakan) dengan nilai $\mathrm{p}<0.05$ dan besarnya pengaruh adalah $30.8 \%$. Pendidikan kesehatan, pendidikan dan informasi sebelumnya berpengaruh terhadap peningkatan kepercayaan kesehatan (keparahan yang dirasakan) dengan nilai $\mathrm{p}<0.05$ dan besarnya pengaruh adalah $31 \%$. Pendidikan kesehatan, dan informasi sebelumnya berpengaruh terhadap peningkatan kepercayaan kesehatan (hambatan yang dirasakan) dengan nilai $\mathrm{p}<0.05$ dan besarnya pengaruh adalah $14.8 \%$. Pendidikan kesehatan, dan informasi sebelumnya berpengaruh terhadap peningkatan kepercayaan kesehatan (efikasi diri) dengan nilai $\mathrm{p}<0.05$ dan besarnya pengaruh adalah $26.8 \%$. Pendidikan kesehatan, dan informasi sebelumnya berpengaruh terhadap peningkatan kepercayaan kesehatan (isyarat untuk melakukan) dengan nilai $\mathrm{p}<0.05$ dan besarnya pengaruh adalah $32.4 \%$.

\section{PEMBAHASAN}

Hasil penelitian menunjukkan lebih dari setengah pendidikan responden adalah pendidikan menengah yaitu SMA. Hasil penelitian yang dilakukan oleh Compaore et al., tingkat pendidikan berpengaruh terhadap keikutsertaan wanita melakukan skrining untuk yang pertama kali. ${ }^{14}$ Pada penelitian ini dijelaskan bahwa tingkat pendidikan akan memberi pengaruh responden untuk lebih mengetahui suatu penyakit, dan dapat mengambil keputusan untuk melakukan skrining bahkan melakukan vaksinasi HPV untuk mereka sendiri dan untuk anak-anak mereka. Pendidikan membantu wanita dalam meningkatkan perilaku untuk mencapai kesehatan yang optimal. Lebih dari setengah pekerjaan pada kelompok perlakuan adalah bekerja, sedangkan pada kelompok kontrol mayoritas responden tidak bekerja. Menurut Compaore et al., wanita yang bekerja cenderung untuk mencari pelayanan kesehatan untuk melakukan skrining. ${ }^{14}$ Pemeriksaan IVA dapat dilakukan di puskesmas sebagai tempat pelayanan kesehatan dasar. Ke- untungan pemeriksaan IVA ini menjadi peluang bagi wanita yang tidak bekerja untuk bisa melakukan pemeriksaan IVA karena memiliki waktu yang lebih banyak. Lebih dari setengah kelompok intervensi dan kelompok kontrol sudah pernah mendapatkan informasi kesehatan tentang kanker serviks. Menurut penelitian yang dilakukan oleh Purnamaningrum, informasi kesehatan merupakan salah satu strategi perubahan perilaku karena individu menerima pesan kesehatan yang berguna untuk dirinya. ${ }^{12}$

Hasil penelitian menunjukkan perbedaan pengetahuan yang signifikan dengan nilai $\mathrm{p}<0.001$ sebelum dan setelah diberikan pendidikan kesehatan (pretest-posttest 1, pretest-posttest 2, posttest 1-posttest 2) pada kelompok intervensi dan kelompok kontrol. Peningkatan rata-rata pengetahuan lebih besar pada kelompok intervensi dibandingkan kelompok kontrol. Pengetahuan adalah hasil dari memperoleh informasi yang didapat melalui penginderaan terhadap suatu objek. ${ }^{15}$ Pengetahuan tentang kanker serviks dan skrining kanker servik dengan metode IVA merupakan domain yang penting untuk terbentuknya tindakan berupa kesertaan wanita dalam melakukan skrining IVA. Penelitian yang dilakukan oleh Chinwe \& Udenebonta, responden penelitian relatif memiliki pengetahuan yang baik tentang kanker serviks dan skrining kanker serviks setelah diberikan pendidikan kesehatan. ${ }^{16}$ Pengetahuan dapat memberi pengaruh positif dan membentuk keyakinan sehingga seseorang dapat berperilaku menurut keyakinannya yang diperoleh melalui pendidikan kesehatan. Keberhasilan pendidikan kesehatan dipengaruhi oleh beberapa faktor, salah satunya adalah media. Pada penelitian ini media yang digunakan adalah audiovisual dan booklet. Melalui media ini diharapkan responden mengingat $60 \%$ informasi yang diberikan. ${ }^{17}$ Penelitian yang dilakukan Peate et al., booklet sebagai salah satu media pembelajaran efektif, dibuktikan dengan $91 \%$ responden merasa puas dengan informasi yang diberikan dan mereka mampu memahami materi yang disampaikan, 95\% responden merekomendasikan booklet kepada orang lain sebagai sarana pembelajaran. ${ }^{18} \mathrm{Pe}$ ngukuran posttest 2-posttest 1 tidak terdapat peningkatan rerata pengetahuan yang signifikan. Hal ini disebabkan karena responden tidak mendapat intervensi lagi hanya mengingat kembali informasi 
yang pernah diberikan. Pada kelompok intervensi responden masih membawa booklet untuk dipelajari di rumah, tetapi pada kelompok kontrol hanya dengan media audiovisual dan diberikan sekali pada minggu I sehingga kemungkinan responden lupa karena jarak pemberian pendidikan kesehatan pada posttest 1 dengan posttest 2 cukup panjang yaitu 3 minggu.

Hasil penelitian didapatkan peningkatan rerata sikap yang bermakna pada kedua kelompok yaitu saat pretest-posttest 1 , pretest-posttest 2 dan peningkatan rata-rata sikap lebih besar pada kelompok intervensi dibandingkan dengan kelompok kontrol. Hasil penelitian ini mendukung penelitian sebelumnya yang mengatakan bahwa pendidikan kesehatan memberikan pengaruh yang positif terhadap peningkatan sikap responden tentang kanker serviks dan skrining kanker serviks. ${ }^{18}$ Pendidikan kesehatan merupakan kombinasi pengalaman belajar yang dirancang dengan menggunakan berbagai metode untuk mengubah sikap individu dan masyarakat dengan meningkatkan pemahaman mereka tentang kesehatan dan penyakit. Metode yang tepat dalam memberikan informasi akan merangsang sikap kesehatan yang positif dalam upaya meningkatkan kesehatan. Responden pada kelompok intervensi lebih tinggi peningkatkan sikap karena disamping mereka mendapatkan informasi melalui audiovisual, mereka juga mempelajari booklet dan membawa media tersebut pulang, sehingga ada kesempatan untuk bisa membaca kembali booklet saat dirumah.

Penelitian ini juga didukung oleh penelitian yang dilakukan oleh Love \& Tanjasiri, media pembelajaran menggunakan video dan brochure efektif dalam meningkatkan sikap wanita tentang kanker serviks dan skrining kanker serviks dengan metode Pap Smear. ${ }^{19}$ Pengukuran posttest 1posttest 2 , rata-rata peningkatan sikap pada kelompok intervensi lebih besar dibandingkan kelompok kontrol. Hal ini terjadi karena responden dalam hal ini tidak lagi mendapatkan intervensi kesehatan dan mereka hanya mengingat kembali materi yang sudah pernah diberikan sebelumnya dan juga jarak waktu yang lama dimana responden menilai sikap pada minggu I, kemudian ada jeda waktu 3 minggu untuk mereka menilai sikap kembali yaitu pada minggu IV dan tidak ada pengulangan informasi kesehatan, sehingga responden kemungkinan lupa.

Berdasarkan hasil analisa data menggunakan uji Wilxocon didapatkan adanya perbedaan komponen kepercayaan kesehatan yang bermakna pada kelompok intervensi yaitu kerentanan yang dirasakan, manfaat yang dirasakan, isyarat untuk melakukan dan efikasi diiri pada saat pengukuran pretest-posttest 1 dan pretest - posttest 2 dengan nilai $\mathrm{p}<0.0 .5$. Menurut Janz et al cit Frankenfield., Daryani et al, kepercayaan kesehatan atau Health Belief Model mampu menciptakan keinginan masyarakat untuk mengambil langkah pencegahan, mencari pelayanan kesehatan dan mengontrol kondisi penyakit dan penggunaan media audiovisual seperti video, film berpengaruh terhadap peningkatan kepercayaan kesehatan responden dalam melakukan skrining. ${ }^{20,21}$ Pendidikan kesehatan yang diberikan kepada individu atau masyarakat, diharapkan dapat meningkatkan keyakinan mereka untuk lebih berperilaku hidup sehat dengan mulai mampu mengetahui risiko penyakit yang dimiliki, keparahan tentang suatu penyakit, manfaat melakukan pencegahan penyakit, mencari layanan kesehatan untuk memeriksakan kesehatan dan melakukan perilaku hidup sehat. Selain itu, pendidikan kesehatan dapat meningkatkan keyakinan mereka bahwa mereka berisiko mengalami kanker serviks sehingga mereka akan berupaya mencari pelayanan kesehatan untuk melakukan skrining kanker serviks.

Pengukuran posttest 1-posttest 2, tidak terdapat perbedaan yang bermakna setelah diberikan pendidikan kesehatan. Hal ini dikarenakan bahwa masih ada beberapa wanita yang masih memiliki kendala untuk meningkatkan kepercayaan kesehatan melakukan skrining seperti rasa malu melakukan pemeriksaan, takut bila hasil pemeriksaan positif, takut dimasukkan alat ke dalam genetalia. Hasil penelitian ini sejalan dengan penelitian Purnamaningrum, bahwa hambatan seperti rasa malu dan takut menjadi faktor yang kuat terhadap keyakinan responden untuk melakukan skrining. ${ }^{12}$

Pada komponen keparahan yang dirasakan, manfaat yang dirasakan dan hambatan yang dirasakan tidak didapatkan peningkatan rata-rata. Hal ini dapat disebabkan oleh beberapa faktor seperti, beberapa responden mengungkapkan bahwa mereka merasa sehat dan tidak perlu untuk melakukan pemeriksaan bila tidak ada gejala. Temuan 
ini konsisten dengan penelitian Purnamaningrum, kebanyakan perempuan tidak memiliki keyakinan akan manfaat skrining. ${ }^{12}$

Berdasarkan data didapatkan peningkatan rata-rata yang bermakna antara kerentanan yang dirasakan, efikasi diri, dan isyarat untuk melakukan setelah diberikan pendidikan kesehatan antara kedua kelompok baik intervensi dan kontrol untuk tiga kali pengukuran dengan nilai $\mathrm{p}=0.000$ dan nilai $\mathrm{p}<0.05$ pada komponen keparahan yang dirasakan dan manfaat yang dirasakan untuk pengukuran pretest-posttest 1 , pretest-posttest 2 , dan nilai $\mathrm{p}<0.05$ pada komponen hambatan yang dirasakan untuk pengukuran pretest-posttest 2 . Peningkatan kepercayaan kesehatan ini lebih besar pada kelompok intervensi dibandingkan dengan kelompok kontrol. Hal ini sejalan dengan penelitian yang dilakukan oleh Daryani et al., Pirzadeh et al., bahwa pendidikan kesehatan sebagai salah satu strategi dalam meningkatkan kepercayaan kesehatan individu tentang kanker serviks dan skrining kanker serviks. ${ }^{21,22}$

Pendidikan kesehatan memberi pengaruh yang baik kepada masyarakat untuk meningkatkan kepercayaan kesehatan mereka, sehingga masyarakat terdorong untuk mau melakukan skrining karena mereka lebih menyadari bahwa mereka berisiko terkena kanker serviks. Setelah diberikan intervensi pendidikan kesehatan, kelompok intervensi lebih banyak yang melakukan skrining IVA dibandingkan dengan kelompok kontrol. Menurut Green et al cit Glanz et al., Rosser et al., pendidikan kesehatan adalah praktik kesehatan yang dilakukan untuk merubah perilaku individu, kelompok, dan populasi yang lebih besar ke arah perilaku yang lebih baik, dan informasi yang benar akan memberikan stimulasi yang positif tentang perilaku hidup sehat., ${ }^{723}$ Pendidikan kesehatan pada penelitian ini sangat bermanfaat bagi responden, karena responden menjadi lebih memahami tentang kanker serviks dan manfaat skrining, responden dalam penelitian ini belum pernah melakukan skrining sebelumnya.

Dari hasil uji multivariat, didapatkan bahwa pendidikan dan penghasilan tidak berpengaruh terhadap peningkatan pengetahuan. Pendidikan dan penghasilan tidak berpengaruh langsung pada meningkatnya pengetahuan karena ada beberapa faktor yang bisa mempengaruhi meningkatnya pengetahuan seperti pemberian informasi yang benar dan dari sumber lain yang tersedia, selain itu ada faktor pendukung lain seperti media pembelajaran yang efektif, informasi kesehatan yang diberikan benar dengan komunikasi yang efektif. Hal ini sejalan dengan penelitian yang dilakukan Abiodun et al, bahwa pendidikan tidak berpengaruh secara signifikan terhadap pengetahuan. ${ }^{24}$ Penghasilan dan informasi sebelumnya berpengaruh terhadap peningkatan sikap. Informasi akan memberikan landasan kognitif dan afektif untuk menilai sesuatu sehingga dapat membentuk sikap terhadap objek tertentu. Harga pemeriksaan IVA yang dilakukan di Puskesmas Pacarkeling adalah Rp. 15.000 setiap kali pemeriksaan. Sehingga dengan penghasilan tersebut, masih bisa dijangkau oleh responden, dan tidak menjadi hambatan bagi setiap wanita diwilayah kerja Puskesmas Pacarkeling untuk ikut serta melakukan skrining IVA. Hal ini sejalan dengan penelitian yang dilakukan oleh Purnamaningrum, bahwa informasi kesehatan adalah salah satu strategi untuk merubah perilaku karena individu menerima pesan kesehatan yang berguna untuk dirinya. ${ }^{12}$

Hasil analisa data multivariat, dijelaskan bahwa data demografi tidak berpengaruh terhadap perilaku wanita dalam melakukan skrining IVA. Hal ini sejalan dengan penelitian yang dilakukan oleh McFarland, bahwa data demografi tidak berpengaruh terhadap keikutsertaan melakukan pap smear ${ }^{25}$ Dalam hal ini pendidikan kesehatan yang memiliki pengaruh terhadap keikutsertaan wanita dalam melakukan skrining IVA. Beberapa variabel luar seperti usia, pendidikan, pekerjaan, penghasilan tidak berpengaruh terhadap komponen kepercayaan kesehatan. Faktor yang dapat berpengaruh seperti sumber informasi yang sudah pernah didapatkan dan pendidikan kesehatan. Responden yang merasa bahwa penyakitnya serius atau berat dan mau melakukan tindakan skrining mendapatkan beberapa informasi dari media massa, teman atau keluarga dan mereka berusaha mencari layanan kesehatan untuk mengurangi ancaman kematian. Menurut WHO dan Kemenkes RI, salah satu kelebihan IVA adalah biayanya relatif murah dan mudah terjangkau, sehingga penghasilan tidak menjadi hambatan dalam melakukan skrining IVA. ${ }^{3}$ Dari hasil lembar evaluasi yang diberikan kepada responden, semua responden baik kelom- 
pok intervensi dan kelompok kontrol menyatakan setuju untuk diberikan pendidikan kesehatan diberikan.

\section{KESIMPULAN DAN SARAN}

Pendidikan kesehatan menggunakan media audiovisual dan booklet efektif dalam meningkatkan perilaku responden dalam melakukan skrining IVA di wilayah kerja Puskesmas Pacarkeling Surabaya (Kelurahan Pacarkeling dan Kelurahan Pacarkembang). Bagi Puskesmas Pacarkeling Surabaya perlu mengikutsertakan kader-kader dalam memberikan pendidikan kesehatan yang dilatih oleh Tim Puskesmas sebagai salah satu upaya dalam program meningkatkan keikutsertaan skrining IVA. Peneliti selanjutnya dapat melakukan penelitian yang tujuannya untuk lebih menggali hambatan yang dialami responden dalam melakukan skrining IVA dan menggunakan sampel yang lebih besar lagi.

\section{UCAPAN TERIMAKASIH}

Penulis mengucapkan terimakasih kepada APTIK (Asosiasi Perguruan Tinggi Katolik) yang telah membantu dalam memberikan bantuan dana, Yayasan Pendidikan Kesehatan Arnoldus dan STIKES Katolik St.Vincentius a Paulo Surabaya yang telah mendukung selama studi dan penyelesaian penelitian, para dosen pembimbing Universitas Gadjah Mada Yogyakarta, kader Puskesmas Pacarkeling, Tim Promosi Kesehatan Puskesmas Pacarkeling, dan seluruh responden yang telah terlibat dalam penelitian.

\section{DAFTAR PUSTAKA}

1. Nurwijaya H, Andrijono, Suheimi H. Cegah dan Deteksi Kanker Serviks. Jakarta: Penerbit PT. Elex Media Komputindo Kelompok Gramedia; 2010.

2. WHO IARC. The Global Cancer Atlas 2012 [Internet]. 2012. Available from: http://globocan.iarc.fr/ia/World/atlas.html

3. Kementrian Kesehatan RI. Panduan Program Nasional Gerakan Pencegahan dan Deteksi Dini Kanker Leher Rahim dan Kanker Payudara. Jakarta : Kementrian Kesehatan RI; 2015.

4. Dinas Kesehatan Provinsi Jawa Timur. Profil Kesehatan Provinsi Jawa Timur 2012. Surabaya : Dinas Kesehatan Provinsi Jawa Timur;
2013.

5. Dinas Kesehatan Kota Surabaya. Laporan Jumlah Penderita Kanker Serviks pada 62 Puskesmas di Kota Surabaya. Surabaya : Dinas Kesehatan Kota Surabaya; 2014.

6. Maulana H. Promosi Kesehatan. Jakarta: EGC; 2009.

7. Khademolhosseini F, Noroozi A, Tahmasebi R. The Effect of Health Belief Model-Based Education through Telegram Instant Messaging Services on Pap Smear Performance. Asian Pac J Cancer Prev. 2017;18(8):22212226.

8. Glanz K, Rimer BK, Viswanath K. Health Behavior and Health Education. San Fransisco: Jossey-Bass A Wiley Imprint;2009.

9. Shojaeizaddeh D, Zeinab S, Moeini B, Poorolajal J. The Effect of Educational Program on Increasing Cervical Cancer Screening Behavior among Women in Hamadan, Iran: Applying Health Belief Model. J Res Heal Sci. 2011;11(1):20-5.

10. Frankenfield KM. Health Belief Model of Breast Cancer Screening for Female College Students. 2009;95.

11. Saraswati L. Pengaruh Pendidikan Kesehatan terhadap Pengetahuan tentang Kanker Serviks dan Partisipasi Wanita dlaam Deteksi Dini Kanker Serviks [Tesis]. Surakarta : Universitas Surakarta; 2011.

12. Mintarsih W. Pendidikan Kesehatan Menggunakan Booklet dan Poster dalam Meningkatkan Pengetahuan dan Sikap Remaja tentang Kesehatan Reproduksi di Kabupaten Tasikmalaya [Tesis]. Yogyakarta : Universitas Gadjah Mada; 2007.

13. Srimiyati. Pengaruh Pendidikan Kesehatan Menggunakan Booklet terhadap Pengetahuan dan Gejala Kecemasan Wanita Premenopause [Tesis]. Yogyakarta : Universitas Gadjah Mada; 2014.

14. Purnamaningrum Y. Efektifitas Pendidikan Kesehatan oleh Lay Health Workers (LHWs) dalam Meningkatkan Kesertaan Skrining Kanker Leher Rahim dengan Metode Inspeksi Visual dengan Asam Asetat (IVA) pada Wanita Usia 25-50 Tahun Di Kabupaten Sleman [Tesis]. Yogyakarta : Universitas Gadjah Mada; 2011. 
15. Dahlan MS. Statistik untuk Kedokteran dan Kesehatan : Deskriptif, Bivariat dan Multivariat Dilengkapi Aplikasi dengan Menggunakan SPSS. Jakarta: Salemba Medika; 2013.

16. Compaore S, Ouedraogo CMR, Koanda S, Haynatzki G, Chamberlain RM, Soliman AS. Barriers to Cervical Cancer Screening in Burkina Faso: Needs for Patient and Professional Education. J Cancer Educ. 2016;31(4): 760-766.

17. Notoatmodjo S. Promosi Kesehatan dan Perilaku Kesehatan. Jakarta: Rineka Cipta; 2012.

18. Chinwe ER, Abigail UR. Impact of Health Education on Knowledge, Attitude and Practice of Cervical Cancer Screening Among Secondary School Teachers in Enugu State. J Women's Heal Care. 2015;4(4):4:241.

19. Arsyad A. Media Pembelajaran. Jakarta: Raja Grafindo Persada; 2011.

20. Peate M, Saunders C, Thewes B, Meiser B, Hickey M. Development and Evaluation of an Information Booklet abour Breast Cancer and Early Menopause. Breast J. 2012;18(1):95-6.

21. Love GD, Tanjasiri SP. Using Entertainment-Education to Promote Cervical Cancer Screening in Thai Women. J Cancer Educ. 2015;27(3): 585-590.
22. Daryani S, Shojaeezadeh D, Batebi A, Charati JY, Naghibi A. The Effect of Education Based on a Health Belief Model in Women's Practice with Regard to the Pap Smear Test. J Cancer Policy. 2016;8:51-6.

23. Pirzadeh A, Mazaheri MA. The effect of Education on Women's Practice Based on The Health Belief Model about Pap Smear Test. Int J Prev Med. 2012;3(8): 585-590.

24. Rosser JI, Njoroge B, Huchko MJ. Changing Knowledge, Attitudes, and Behaviors Regarding Cervical Cancer Screening: The Efects of an Educational Intervention in Rural Kenya. Patient Educ Couns. 2015;98(7):884-889.

25. Abiodun O a, Olu-Abiodun OO, Sotunsa JO, Oluwole $\mathrm{F}$ a. Impact of Health Education Intervention on Knowledge and Perception of Cervical Cancer and Cervical Screening Uptake among Adult Women in Rural Communities in Nigeria. BMC Public Health. 2014;14(1):814.

26. McFarland D. Association of Demographic Variables and the Health Belief Model Constructs with Pap Smear Screening among Urban Women in Botswana. Int J Womens Heal. 2013;5:709-716. 